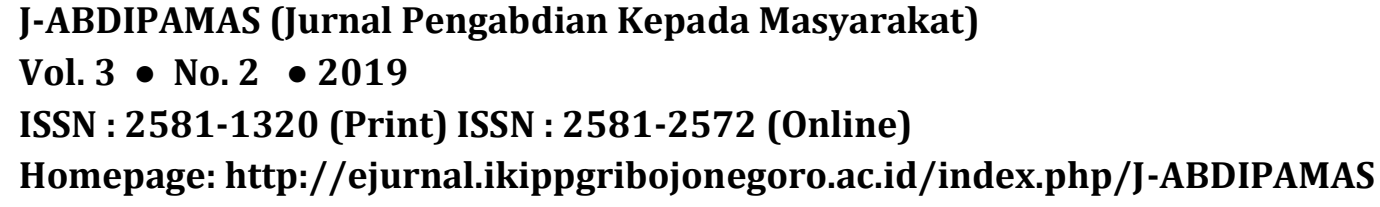

\title{
PENDAMPINGAN BUMDES BIMA SAKTI WELAHAN JEPARA MELALUI INOVASI PRODUK BERBASIS LIMBAH
}

\author{
Santi Andriyani ${ }^{1}$, Achmad Zainuddin ${ }^{2}$, Amrina Rosyada $^{3}$, Ali Shofwan ${ }^{4}$ \\ ${ }^{1}$ Universitas Islam Nahdlatul Ulama Jepara. Email: santi@unisnu.ac.id \\ 2 Universitas Islam Nahdlatul Ulama Jepara. Email: dzain@unisnu.ac.id \\ 3 Universitas Islam Nahdlatul Ulama Jepara. Email: amrosyada92@gmail.com \\ ${ }^{4}$ Universitas Islam Nahdlatul Ulama Jepara. Email: alisofwan1047@gmail.com
}

\begin{abstract}
The partner of this program is the village's business institution (Bumdes) in Karangayar Welahan Jepara named Bumdes Bima Sakti. The main issues are: 1) lack of awareness and knowledge of partners in waste management; and 2) lack of partner creativity in waste-based product innovation. The purpose of this community service program is to increase awareness, education, and also the creativity of partners in waste management and product innovation. The methods used are socialization, training, and evaluation. The results of this program are: 1) creation of waste-based products; 2) The results of the partner evaluation questionnaire regarding the program are very good with an average percentage of $90 \%$.
\end{abstract}

Keywords: Bumdes, waste management, product innovation

\begin{abstract}
ABSTRAK
Mitra dari program ini adalah Badan Usaha Milik Desa (Bumdes) yang ada diKarangayar Welahan Jepara bernama Bumdes Bima Sakti. Permasalahan yang utama adalah : 1) kurangnya kesadaran dan pengetahuan mitra dalam pengelolaan sampah; dan 2) kurang kreatifitas mitra dalam inovasi produk berbasis limbah. Tujuan dari program pengabdian ini adalah untuk meningkatkan kesadaran, edukasi, dan juga kreatifiats mitra dalam pengelolaan sampah dan inovas produk. Metode yang digunakan adalah sosialisasi, pelatihan, dan evaluasi. Hasil dari program ini adalah: 1) terciptanya produk berbasis limbah; 2) Hasil angket evaluasi mitra mengenai program terbilang sangat baik dengan prosentase rata-rata $90 \%$.
\end{abstract}

Kata Kunci: bumdes, pengelolaan sampah, inovasi produk

\section{PENDAHULUAN}

Mitra pada program pengabdian ini adalah Badan Usaha Milik Desa ( Bumdes) Bima Sakti yang berada di desa Karanganyar Welahan Jepara. Berdasarkan letak geografis wilayah, Desa Karanganyar berada di sebelah selatan kota Kabupaten Jepara. Desa Karanganyar merupakan salah satu desa di Kecamatan Welahan Kabupaten Jepara, dengan jarak tempuh ke kota Kecamatan 7 km, dan ke kota Kabupaten 25 km, dan dapat ditempuh dengan kendaraan 50-60 menit. Batas desa sebelah barat dengan desa Ujung 
Pandan, sebelah utara berbatasan dengan desa Sidi Gede, sebelah selatan berbatasan dengan desa Rejo Sari ( Kecamatan Mijen Kabupaten Demak ), dan sebelah timur berbatasan dengan desa Guwosobokerto. Berikut Profil Bumdes Bima Sakti.

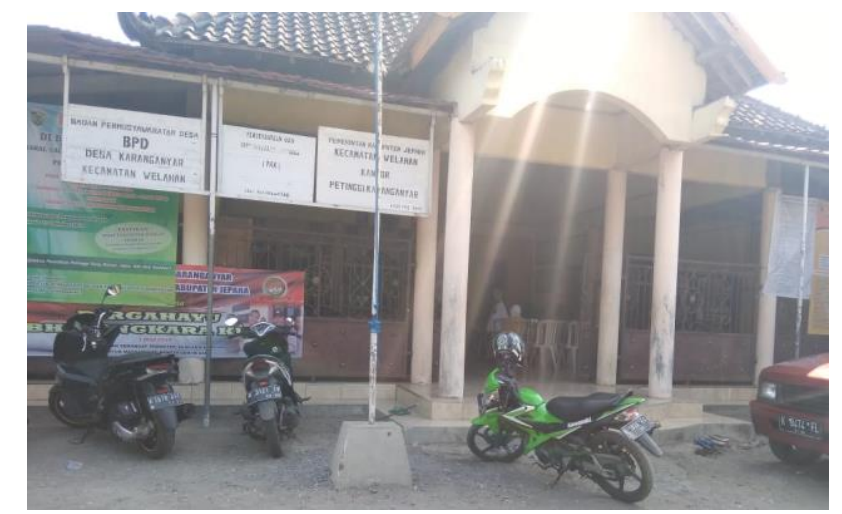

Gambar 1. Kantor Bumdes

\begin{tabular}{|c|c|c|}
\hline 1 & Nama Bumdes & Bima Sakti \\
\hline 2 & Status & $\begin{array}{l}\text { Akta Pendirian Nomor } 20 \text { oleh Notaris } \\
\text { Mulung Estu Prakoso, SH Tanggal } 26 \\
\text { Maret } 2014\end{array}$ \\
\hline 4 & Alamat & $\begin{array}{l}\text { Balai Desa Karanganyar kecamatan } \\
\text { Welahan Kabupaten Jepara }\end{array}$ \\
\hline 5 & Nama Ketua Bumdes & Muh Saiful Amri \\
\hline 6 & Dokumen & $\begin{array}{ll} & \text { Akta Notaris Pendirian Bumdes } \\
\circ & \text { Perdes Tentang Bumdes Bima } \\
& \text { Sakti }\end{array}$ \\
\hline 7 & Program & $\begin{array}{ll}\text { O Usaha Ekonomi Desa Simpan } \\
\text { Pinjam (UEDSP) } \\
\text { Menuju Desa eduwisata kampung } \\
\text { dolanan anak }\end{array}$ \\
\hline
\end{tabular}

Berdasarkan Perdes Desa Karanganyar Nomor 2 Tahun 2014, maksud secara umum pembentukan Bumdes Bima Sakti Desa Karanganyar adalah untuk mewadahi potensi usaha perekonomisn masyarakat yang ada di desa Karanganyar. Ini sesuai dengan tujuan Bumdes yaitu Keberadaan BUMDes adalah untuk memperkuat ekonomi rakyat desa. (Sutoro Eko, dkk. 2015).

Sesuai dengan Akta Notaris Pendirian Bumdes Bima Sakti Nomor 20 pada tanggal 26 Maret 2014, menyatakan bahwa tujuan dari pembentukan Bumdes Bima Sakti adalah: a) meningkatkan perekonomian Desa; b) Meningkatkan Pendapatan Asli (PADes); 3) Meningkatkan pengolahan potensi desa yang sesuai dengan kebutuhan desa; 4) menjadi tulang punggung pertumbuhan dan pemerataan ekonomi pedesaan. 
Fokus program pada Bumdes Bima Sakti adalah perencanaan menuju “ Eduwisata Kampung Dolanan Anak" dengan tahapan awal adalah mewujudkan lingkungan yang bersih. namun berdasarkan observasi dan wawancara yang telah dilakukan , ada beberapa kendala yang dialami mitra dalam pelaksanakan peningkatan potensi desa. Kendala tersebut meliputi aspek SDM dan juga aspek lingkungan. Aspek SDM pengelola Bumdes merupakan aspek yang terpenting dalam peningkatan perekonomian dan potensi desa (Chikamawanti: 2015).

Berdasarkan hasil observasi, permasalahan yang paling menonjol pada mitra adalah banyaknya sampah limbah mainan anak yang tidak diolah dan tidak ramah lingkungan. Sampah merupakan sisa pakai dari kemanfaatan yang digunakan oleh manusia (Hayat \& Zayadi: 2018). Masyarakat desa karanganyar merupakan masyarakat penghasil mainan anak tradisisonal. Setiap hari, tiap pengrajin dapat memproduksi mainan anak sampai 100 buah, oleh karena itu sampah limbah mainan juga banyak dan tidak dikelola. Dengan kata lain, laju produksi sampah terus meningkat, tidak saja sejajar dengan laju pertumbuhan penduduk tetapi juga sejalan dengan meningkatnya pola konsumsi masyarakat (Roswan dan Hadiyarno: 2011). Berikut kondisi sampah yang tidak dikelola:
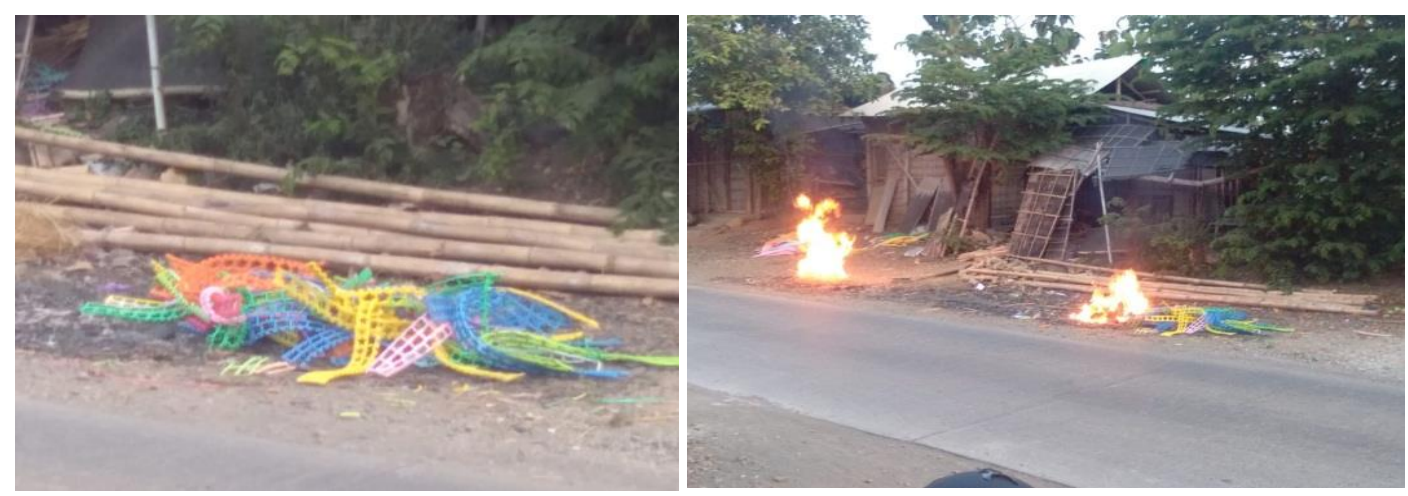

Gambar 2. Sampah limbah Mainan Anak dan tidak diolah

Permasalahan yang timbul akibat sampah limbah mainan ini adalah tidak adanya tempat atau penampung dan pengelolaan sampah di desa, sehingga para masyarakat hanya secara bebas membuang sampah di depan rumah kemudian dibakar. Sebagian besar masyarakat tidak memiliki tempat sampah apalagi tempat pengelolaan sampah.

Sesuai dengan permasalahan di atas, Bumdes dan tim PKM membuat program yaitu inovasi produk tempat sampah berbasis limbah. Tujuan dari PKM ini adalah: 1) 
Meningkatkan kreatifiats dan inovasi mitra mengenai produk berbasis limbah; 2 meningkatkan pengetahuan dan kesadaran mitra tentang pentingnya pengelolaan sampah; 3) Hasil produk digunakan untuk memfasilitasi masyarakat dalam pengumpulan sampah .

\section{METODE PELAKSANAAN}

Sesuai dengan solusi di atas, maka metode pelaksanaan pada pengabdian ini adalah: edukasi, training, dan pendampingan. Berikut kami tampilkan deskripsinya dalam tabel berikut:

\begin{tabular}{|c|c|c|}
\hline No & Kegiatan & Langkah-langkah \\
\hline & Persiapan & \\
\hline 1 & $\begin{array}{l}\text { Koordinasi Mitra terkait persiapan } \\
\text { kegiatan PKM }\end{array}$ & 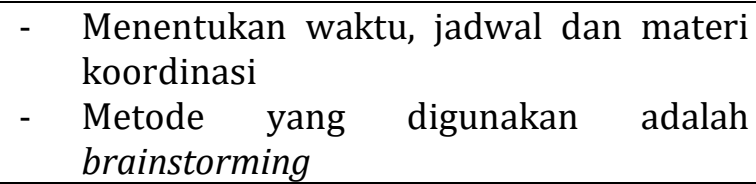 \\
\hline 2 & $\begin{array}{l}\text { Pembelian bahan-bahan untuk } \\
\text { pelaksanaan PKM }\end{array}$ & $\begin{array}{l}\text { - Menglist bahan dan membuat sample } \\
\text { produk }\end{array}$ \\
\hline & Pelaksanaan & \\
\hline 1 & $\begin{array}{l}\text { Sosialisasi tentang pentingnya inovasi } \\
\text { produk berbasis limbah }\end{array}$ & 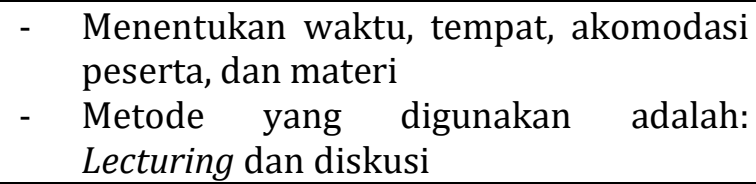 \\
\hline 2 & $\begin{array}{l}\text { Pengendalian Pencemaran dan } \\
\text { Pengelolaan Lingkungan Hidup, Best } \\
\text { Practice Pengelolaan sampah dan } \\
\text { Bank sampah }\end{array}$ & 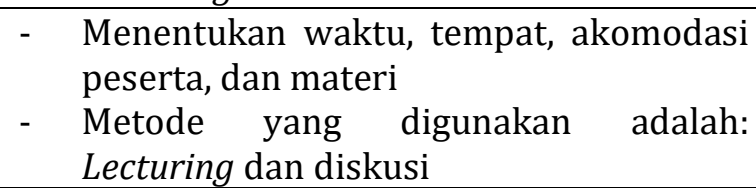 \\
\hline 3 & $\begin{array}{l}\text { Pelatihan inovasi produk berbasis } \\
\text { limbah }\end{array}$ & $\begin{array}{l}\text { - } \quad \text { Menentukan waktu, tempat, akomodasi } \\
\text { peserta, dan materi dan bahan } \\
\text { - } \text { Metode yang digunakan adalah: praktik } \\
\text { dan demonstrasi }\end{array}$ \\
\hline 4 & Pendampingan dan evaluasi program & $\begin{array}{l}\text { Menentukan target dan instrumen } \\
\text { evaluasi } \\
\text { Metode yang digunakan adalah: } \\
\text { pendampingan dan angket }\end{array}$ \\
\hline
\end{tabular}

\section{HASIL DAN PEMBAHASAN}

Sesuai dengan metode pelaksanaan yang telah disusun, maka kegiatan ini dimulai dengan sosialisasi tentang bank sampah dan pengelolaannnya. Peserta dari kegiatan ini adalah perwakilan dari bumdes dan unsur-unsur yang ada dipemerintahan juga masyarakat. Acara ini dimulai dengan sambutan dari pak petinggi sekaligus membuka acara. 


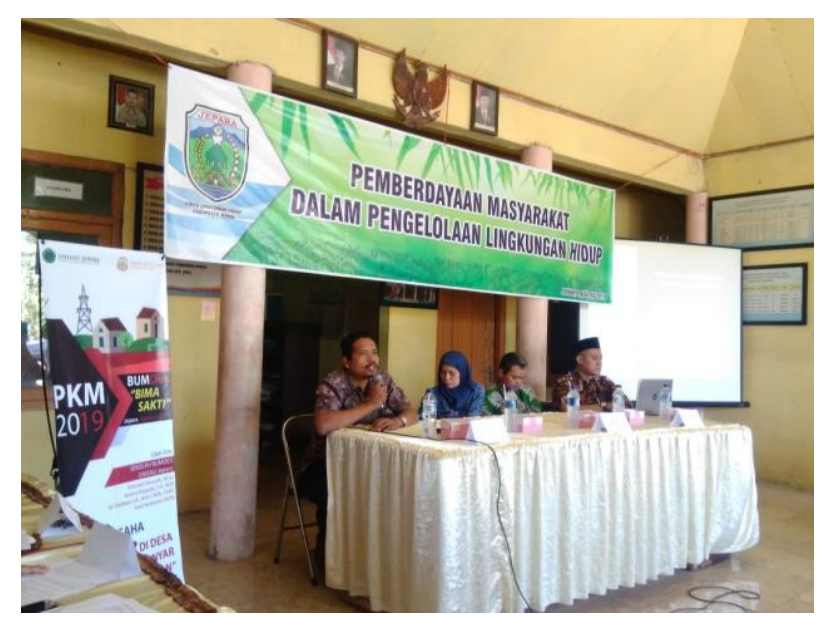

Gambar 3. Pembukaan secara resmi oleh Pak Petinggi

Tim juga berkolaborasi dengan Dinas lingkungan Hidup Kabupaten Jepara untuk kegiatan sosialisasi ini. Penyampaian materi pertama oleh Ibu Kabid Bidang pengelolaan sampah yaitu Ibu Nurnaini, SE, MM. Beliau berbicara tentang Pengendalian Pencemaran dan Pengelolaan Lingkungan Hidup. Metode yang digunakan adalah lecturing dan menggunakan media ppt.

Penyampaian materi selanjutnya mengenai best practice pengelolaan sampah , yang diisi oleh Muhammad Safruddin, S.Sos, M.Si. Metode yang digunakan dalam penyampain materi adalah watching video dan braistorming.

Selanjutnya adalah penyampaian materi tentang bank sampah. Ini disampaikan oleh Ibu Fitri perwakilan dari kader lingkungan hidup. Tema yang diusung adalah tentang Bank Sampah. Metode yang digunakan adalah lecturing dan diskusi. Program bank sampah juga salah satu program yang penting karena menumbuhkan partisipasi masyarakat. Kegiatan ini bersifat social engineering yaitu memberikan edukasi kepada masyarakat bagaimana memiliah sampah sekaligus menumbuhkan kesadaran dan perhatian masyarakat mengenai pengelolaan sampah secara bijak (Suryani: 2014).

Dari kesemua materi diatas merupakan bagian dari program tim untuk meningkatkan pengetahuan dan kesadaran mitra mengenai pentingnya pengelolaan sampah. Ini sesuai dengan yang disampaikan oleh Sulistiorini \& Gutama (2016) bahwa partisipasi dan kontribusi masyarakat dalam pengelolaan sampah dapat meningkatkan kesadaran masyarakat akan pentingnya kebersihan lingkungan sekitar yang hijau, sehat, dan bersih.

Selanjutnya adalah materi praktik. Tim melakukan pelatihan inovasi produk dari limbah tong cat. Pertama tim menyampaian materi tentang pentingnya inovasi produk 
dari limbah. Metode yang digunakan adalah lecturing dan media yang digunakan adalah ppt.

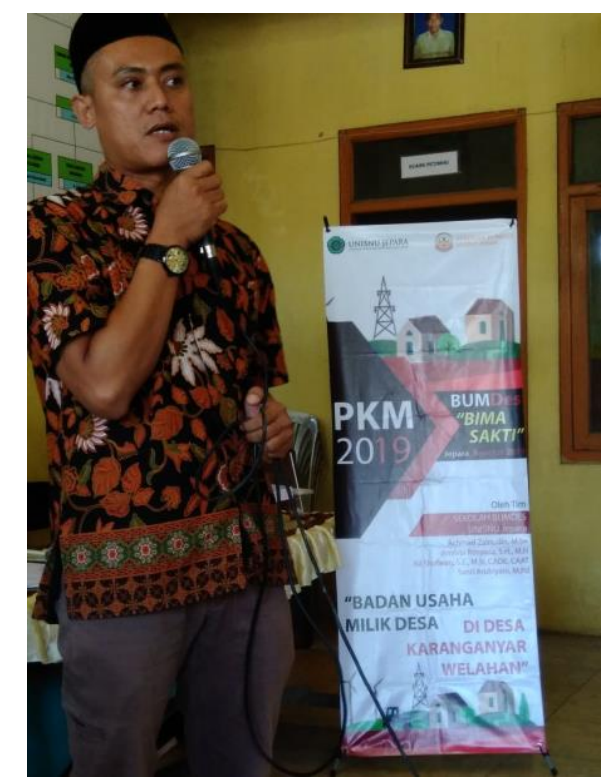

Gambar 4. Penyampaian materi inovasi Produk

Kegiatan yang inti adalah pelatihan inovasi produk. Tim memfasilitasi dan mendampingi mitra dalam melakukan proses pembuatan tong sampah yang edukatif dan bernilai kearifan lokal. Metode pelatihan yang telah dilakukan adalah praktik dan demonstrasi. Adapun tahapan pembuatan tong sampah dimaksud adalah:

Pertama, limbah kaleng cat dibersihkan terlebih dahulu dan di amplas terlebih dahulu supaya dalam pengecatan dasar bisa maksimal.

Kedua, pengecatan untuk seluruh tong dengan berbagai warna. Cat yang digunakan adalah mowilex. Hasilnya setiap bahan tong memiliki warna yang bervariasi dan menarik untuk dipandang.

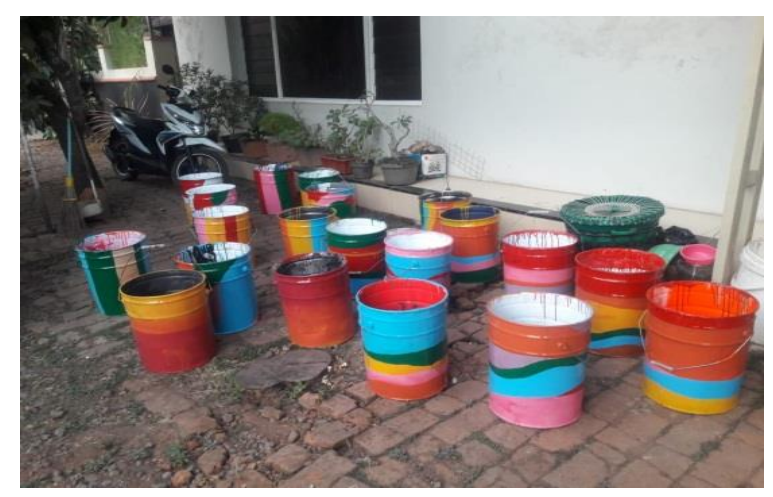

Gambar 5. Tahap Pengecatan dasar 
Supaya tong sampah tersebut terlihat menarik, maka langkah selanjutnya adalah pembuatan pola gambar. Gambar yang diambil adalah kartun-kartun animasi anak tetapi dipadukan dengan kearifan lokal yang ada di karanganyar .

Selanjutnya, mitra melakukan tahapan melukis gambar yang sudah terpola. Tim membagi menjadi 4 kelompok untuk tahapan melukis ini. Para mitra dengan antusias melakulan tahapan melukis ini.
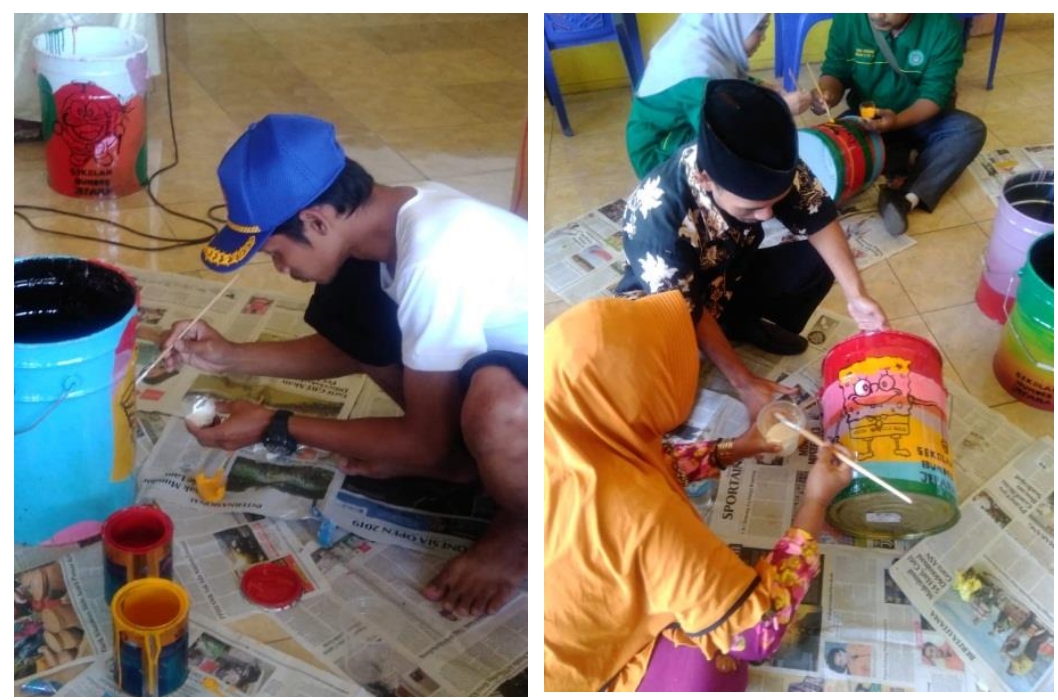

Gambar 6. Tahapan Melukis Gambar pada tong

Yang terakhir adalah finishing dan pengeringan. Hal ini dilakukan supaya lukisannya tahan lama dan tidak rusak. Pengeringan ini berlangsung kira-kira 10-15 menit. Hasilnya produk terlihat menarik dan sesuai dengan harapan mitra.

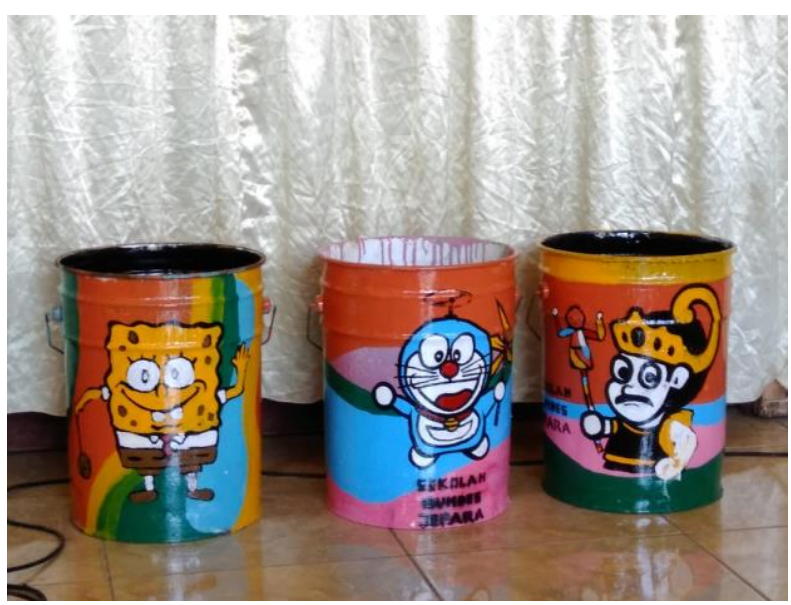

Gambar 7. Tahap finishing 
Setelah pelatihan selesai, tim membagikan angket kepada mitra dengan tujuan untuk mengetahui sejauhmana program tim berjalan dengan maksimal. Angket tersebut terdiri dari 3 pernyataan besar yaitu mengenai kecakapan tim dalam penyampaian materi, pendampingan, dan kebermanfaatan produk. Adapun hasilnya, untuk pernyataan pertama memperoleh nilai sangat baik dengan prosentase $80 \%$, sedangkan pernyataan kedua juga memperoleh nilai sangat baik dengan prosentase $85 \%$. Untuk item ketiga memperoleh nilai sangat baik dengan prosentase 90\%. Berikut bagan prosentase yang dimaksud.

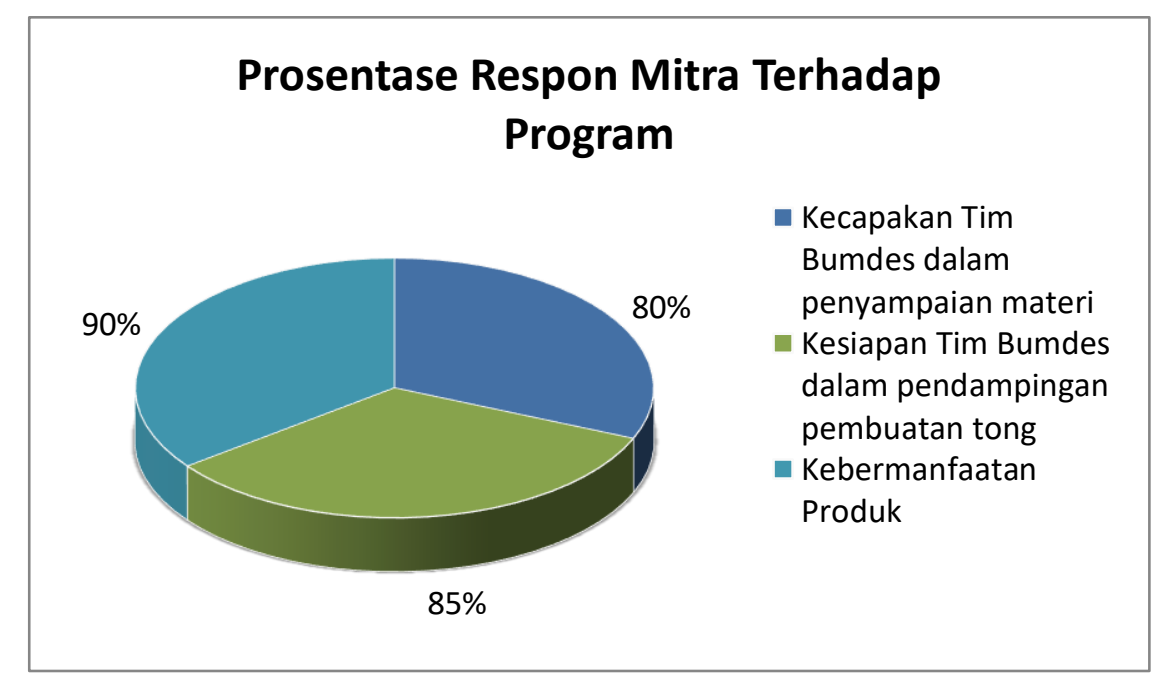

\section{SIMPULAN}

Simpulan dari program ini adalah: a) kegiatan pelatihan inovasi produk dari limbah diawali dengan sosialisasi pengelolaan sampah, sosialisasi tentang bank sampah, materi inovasi produk; b) tahapan dalam pembuatan tong sampah berbasis limbah adalah : 1) pemilahan dan pembersihan kaleng; 2) pengecatan dan penghalusan; 3) pengeringan tahap awal; 4) menggambar pola animasi kartun dan gambar dolanan anak; 5) melukis gambar dengan berbagai warna; 6) finishing; c) Hasil respon mitra terhadap program memperoleh nilai sangat baik.

\section{UCAPAN TERIMA KASIH}

Ucapan terimaksih kami sampaikan kepada UNISNU Jepara melalui LPPM UNISNU atas hibah pengabdian reguler sehingga kegiatan ini dapat terlaksana dengan baik. Tak lupa kami juga mengucapkan terimaksih kepada Sekolah Bumdes Jepara atas 
support dan bimbingannya sehingga pengabdian kepada mitra Bumdes dapat berjalan sesuai harapan.

\section{DAFTAR RUJUKAN}

Chikamawati, Z. (2015). Peran Bumdes Dalam Meningkatkan Pertumbuhan Ekonomi Pedesaan Melalui Penguatan Sumber Daya Manusia.Sustainable Competitive Advantage (SCA), 5(1).

Hayat, H., \& Zayadi, H. (2018). Model Inovasi Pengelolaan Sampah Rumah Tangga. JU-ke (Jurnal Ketahanan Pangan), 2(2), 131-141.

Riswan, R., Sunoko, H. R., \& Hadiyarto, A. (2011). Pengelolaan sampah rumah tangga diKecamatan Daha Selatan. Jurnal Ilmu Lingkungan, 9(1), 31-38.

Sulistiyorini, N. R., Darwis, R. S., \& Gutama, A. S. (2016). Partisipasi masyarakat dalam pengelolaan sampah di lingkungan Margaluyu Kelurahan Cicurug. SHARE: Social Work Journal, 5(1).

Suryani, A. S. (2014). Peran bank sampah dalam efektivitas pengelolaan sampah (studi kasus bank sampah Malang). Jurnal Aspirasi, 5(1), 71-84.

Sutoro Eko, dkk. 2015. Modul Pelatihan Pratugas Pendampingan Desa: Implementasi Undang-Undang Desa Nomor 6 Tahun 2014 Tentang Desa. Kementerian Desa, Pembangunan Daerah Tertinggal dan Transmigrasi 
166 J-Abdipamas, Vol. 3, No. 2 Oktober, 2019 